Journal of Telenursing (JOTING)

Volume 1, Nomor 1, Juni 2019

e-ISSN : 2684-8988

p-ISSN : 2684-8996

DOI: https://doi.org/10.31539/joting.v1i1.540

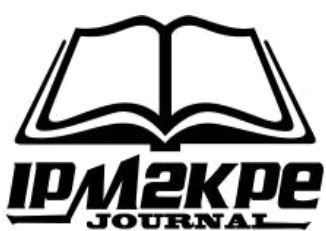

\title{
PERBANDINGAN EFEKTIFITAS RELAKSASI AUTOGENIC DAN MUSIC THERAPY TERHADAP TINGKAT NYERI SETELAH INSERSI VASKULER PASIEN YANG MENJALANI HEMODIALISA
}

\author{
Beti Haerani ${ }^{1}$, Yani Sofiani ${ }^{2}$, Anwar Wardi ${ }^{3}$ \\ Universitas Muhammadiyah Jakarta ${ }^{1,2,3}$ \\ betihaerani@gmail.com ${ }^{1}$
}

\begin{abstract}
ABSTRAK
Tujuan penelitian ini adalah untuk membandingkan efektifitas relaksasi autogenic dan music therapy terhadap tingkat nyeri pada pasien HD saat insersi vaskuler. Penelitian ini menggunakan study quasy eksperimen dengan rancangan post test design. Hasil penelitian, menggunakan analisa $t$ test independen menunjukkan tidak terdapat perbedaan tingkat nyeri yang signifikan setelah insersi vaskuler pada pasien HD yang diberikan relaksasi autogenic dengan pasien HD yang diberikan music therapy serta pasien HD yang diberikan gabungan dari relaksasi autogenic dan music therapy ( $\mathrm{p}$ value $=0,896$, alpha $=0,05)$. Rata-rata tingkat nyeri pada kelompok music therapy yakni $(5,00)$, relaksasi autogenic dengan rata-rata tingkat nyeri $(5,27)$ dan rata-rata tingkat nyeri pada kelompok gabungan antara relaksasi autogenic dan music therapy yakni $(5,06)$. Simpulan, music therapy memiliki tingkat nyeri lebih rendah dibandingkan relaksasi autogenic dan gabungan keduanya karena saat pelasanaan music therapy responden tidak membutuhkan upaya mental yang besar untuk tetap dalam keadaan fokus.
\end{abstract}

Kata Kunci: Hemodialisa, Music Therapy, Relaksasi Autogenic, Tingkat Nyeri

\begin{abstract}
The aim of this study was to compare the effectiveness of autogenic relaxation and music therapy on the level of pain in HD patients during vascular insertion. This study used a quasy experimental study with a post test design. The results of the study, using independent $t$ test analysis showed that there was no significant difference in pain levels after vascular insertion in HD patients who were given autogenic relaxation with HD patients who were given music therapy and HD patients who were given a combination of autogenic relaxation and music therapy $(p$ value $=0.896$, alpha $=0.05)$. The average pain level in the music therapy group was (5.00), autogenic relaxation with an average pain level (5.27) and an average pain level in the combined group between autogenic relaxation and music therapy (5.06). In conclusion, music therapy has a lower level of pain than autogenic relaxation and a combination of the two because the respondent does not require a lot of mental effort to stay focused.
\end{abstract}

Keywords: Hemodialysis, Music Therapy, Autogenic Relaxation, Pain Level 


\section{PENDAHULUAN}

Gagal ginjal stadium akhir merupakan penurunan fungsi ginjal yang bersipat menetap disertai kegagalan ginjal mempertahankan fungsi metabolisme, keseimbangan cairan dan elektrolit (Smeltzer \& Bare, 2008). Terapi penggantian fungsi ginjal merupakan terapi yang banyak dipilih oleh pasien GGK tahap akhir. Terapi pengganti fungsi ginjal dapat berupa dialisis atau transplantasi ginjal. Dialisis terdiri atas hemodialisa dan continuing ambulatory peritoneal dialysis (CAPD) (Sudoyo et al., 2006).

Peningkatan jumlah pasien PGK stadium akhir memerlukan dialisis sangat signifikan setiap tahunnya, ini dapat dilihat dari data Indonesian Renal Registry (IRR) selama tahun 2013 jumlah pasien tercatat yakni 15.120 orang, responden aktif 9.396 orang dengan jumlah total tindakan hemodialisa 706. 527 kali. Pada tahun 2015 jumlah pasien tercatat yakni 51.604 orang, responden aktif 21.050 orang dan pasien baru sebanyak 30.554 orang (Indonesian Renal Registry, 2015).

Hemodialisa merupakan suatu proses pengeluaran sisa metabolisme, cairan dan elektrolit. Proses ini sama dengan proses yang terjadi pada ginjal, namun proses hemodialisa dilakukan dalam sebuah mesin yang terdiri atas komponen dialiser atau penyaring, larutan dialisat dan selang sebagai penghubung antara mesin dengan tubuh (Black \& Hawk, 2009). Setelah darah diambil untuk disaring dalam mesin dialiser dibutuhkan akses pembuluh darah. Insersi vaskuler bertujuan untuk mencegah terjadinya trauma pada vena karena penusukan berulang-ulang. Tindakan insersi vaskuler saat proses hemodialisa memberikan rasa ketidaknyamanan dan rasa nyeri (Pardede, 2006).

Menurut penelitian Suko (2016) mengatakan bahwa dari sampel 38 pasien hemodialisa rata-rata memiliki tingkat nyeri 7 dengan menggunakan skala ukur visual analoge scale, dapat disimpulkan bahwa rata-rata pasien hemodialisa mengalami rasa nyeri setelah insersi vaskuler hemodialisa. Berdasarkan hasil studi pendahuluan di RSUD Tangerang ketika ditanyakan terhadap 10 pasien yang sedang menjalani hemodialisa semua pasien mengatakan merasakan nyeri setelah insersi vaskuler.

Nyeri merupakan suatu pengalaman sensorik dan emosional yang tidak menyenangkan dan berhubungan dengan kerusakan jaringan baik kerusakan aktual maupun potensial (International Association for the Study of Pain, 1979). Respon seseorang terhadap nyeri berbeda-beda sesuai tingkat perkembangan serta pengalaman nyeri sebelumnya. Proses fisiologis nyeri dimulai dari adanya rangsangan kimia, mekanik atau trauma kemudian saraf sensorik memberikan sinyal adanya bahaya ke otak melalui perantara serabut saraf. Aktivasi neuron diantara saraf sekaligus dapat merangsang melepaskan beberapa hormon yang dapat dilihat dari adanya perubahan denyut nadi, tekanan darah dan irama pernafasan (Smeltzer \& Bare, 2008).

Intervensi farmakologi diantaranya dengan menggunakan analgesik topikal. Sementara intervensi nonfarmakologi yaitu tindakan akupuntur, massage, relaksasi, deep breathing, imagery, reiky, therapeutic touch, pemberian nutrisi, membaca, mendengarkan musik, memegang orang tercinta atau mainan (Lindquist et al., 2014). Penelitian yang dilakukan oleh Alhani \& Hajizadeh (2008) menunjukkan adanya pengaruh program distraksi terhadap penurunan nyeri pada responden yang dipasang kanulasi hemodialisa. Penelitian yang dilakukan oleh Dina (2016) menyatakan bahwa relaksasi autogenic mampu menurunkan nyeri pada pasien dengan ulkus peptikum. Autogenic merupakan latihan berkonsentrasi atau mengasah kemampuan untuk fokus 
dengan menggunakan persepsi tubuh yang difasilitasi oleh sugesti diri sendiri (Micah \& Sadigh, 2001).

Terdapat empat fase dalam latihan otogenik yaitu fase perasaan berat, perasaan hangat, ketenangan jantung dan ketenangan pernafasan. Berikan waktu sekitar 3-4 menit pada tiap fase untuk mengulang instruksi yang diberikan sampai merasa hangat, berat dan tenang. Keseluruhan fase hanya berlangsung 15 menit. Jika sudah selesai, tetap pada posisi selama beberapa menit dan coba menempatkan perasaan rilek kedalam memori sehingga dapat mengingatnya saat merasa stress (Greenberg, 2002). Terapi autogenic termasuk dalam kontrol eksekutif tubuh dimana tubuh sudah melakukan kontrol eksekutif sehingga saat saraf sensoris memberikan rangsangan nyeri tubuh memerintahkan pikiran untuk rileks dan otot tidak akan tegang saat insersi.

Manajemen nyeri yang lain untuk menanggulangi nyeri adalah metode distraksi dengan music therapy (Purwanti et al., 2010). Dalam buku Complementary And Alternative Therapies In Nursing by Lindquist et al., (2014) irama yang teratur dapat menyeimbangkan tubuh dan menurunkan nyeri. Tehnik distraksi yang efektif memberi pengaruh baik dalam waktu yang singkat yaitu musik.

Menentukan pemberian intervensi music therapy pada responden hendaklah melalui penilaian, diantara alat yang dikembangkan untuk tujuan ini adalah penilaian instrumen serta informasi tentang seberapa sering music didengarkan; jenis pilihan musik, seniman, kelompok, dan genre yang disukai; dan alasan individu untuk mendengarkan musik. Bagi sebagian orang, tujuan mendengarkan music mungkin untuk bersantai, sedangkan yang lain mungkin lebih suka music yang mengalihkan perhatian, merangsang, dan menyegarkan. Setelah data penilaian dikumpulkan, teknik yang sesuai dengan music tertentu kemudian bisa dirancang dan diimplementasikan (Simon \& David, 2008).

Music religius lebih disukai dan disambut oleh mereka yang tidak mampu menghadiri pelayanan rohani, dan untuk menghadirkan keyakinan akan sembuh pada responden yang memiliki keyakinan akan adanya Tuhan (Lindquish et al., 2014). Berdasarkan penelitian yang dilakukan terbukti bahwa music therapy diberikan 5 menit sebelum tindakan invasif sampai 5 menit sesudah tindakan invasif dapat menurunkan nyeri (Purwanti et al., 2010).

Dari hasil studi pendahuluan di RSUD Tangerang terhadap perawat yang melakukan insersi mengatakan sudah melakukan manajemen nyeri dengan meminta responden melakukan relaksasi nafas dalam namun upaya atraumatic care menggunakan manajemen nyeri non farmakologi dengan relaksasi autogenic dan music therapy belum pernah dilakukan. Hasil Survei terhadap 10 responden yang sedang menjalani hemodialisa didapatkan $100 \%$ mengatakan merasakan nyeri setelah insersi vaskuler saat hemodialisa.

Selama ini banyak penelitian terkait music therapy dan relaksasi autogenic namun jenis responden yang dilibatkan, metode dan durasi pengukuran tingkat nyeri berbeda. Pada penelitian ini metode pemberian relaksasi autogenic dan music therapy diberikan lima menit sebelum insersi sampai dengan lima menit setelah insersi vaskuler hemodialisa serta responden yang dilibatkan mendapatkan intervensi relaksasi autogenic dan music therapy serta ada responden yang mendapatkan gabungan dari relaksasi autogenic dengan music therapy dalam satu waktu, sehingga peneliti tertarik untuk meneliti perbandingan manajemen nyeri mana yang jauh lebih efektif sebagai intervensi kenyamanan pada responden yang menjalani hemodialisa setelah dilakukan insersi akses vaskuler, yaitu music therapy dibandingkan relaksasi autogenic dan 
gabungan music therapy dengan relaksasi autogenic dalam menurunkan tingkat nyeri pada responden yang menjalani hemodialisa di RSUD Kabupaten Tangerang.

\section{METODE PENELITIAN}

Jenis penelitian yang digunakan adalah penelitian analitik dengan menggunakan metode quasi eksperimen dengan pendekatan post test only control group design yaitu berarti bahwa kesimpulan hasil penelitian didapat dengan cara pembandingan post test antara kelompok intervensi. Dalam penelitian ini dibagi kedalam tiga intervensi dari dua kelompok responden yaitu kelompok pertama mendapatkan intervensi relaksasi autogenic dan music therapy dengan jadwal yang berbeda sedangkan kelompok ke dua mendapatkan intervensi gabungan music therapy dengan relaksasi autogenic dalam waktu yang sama.

Populasi dalam penelitian ini adalah semua pasien HD di RSUD tangerang. Teknik pengambilan sampel yakni teknik non probability sampling dengan memakai total sampling (sampling jenuh) yang berjumlah 99 responden HD. Pengukuran tingkat nyeri dilakukan dengan menggunakan Visual Analoge Scale (VAS) dengan skala 0-10 $\mathrm{cm}$. Validasi data langsung dilakukan oleh peneliti bila ada informasi yang kurang jelas dari jawaban masing-masing informan.). Responden yang memenuhi kriteria inklusi diberikan intervensi relaksasi autogenic dan music therapy serta gabungan keduanya yang diberikan 5 menit sebelum tindakan insersi vaskuler HD sampai dengan prosedur selesai. Intervensi dilakukan satu kali dengan penilaian post test satu kali. Pengambilan data dilakukan selama satu bulan pada bulan April sampai dengan Mei 2018.

Data dianalisis dalam bentuk univariat untuk mendeskripsikan karakteristik responden yang terdiri dari usia, jenis kelamin dan lama HD, sedangkan analisa bivariat untuk membandingkan efektifitas intervensi relaksasi autogenic dan music therapy terhadap tingkat nyeri dengan menggunakan uji $t$ paired dan uji $t$ independen. Validasi data langsung dilakukan oleh peneliti bila ada informasi yang kurang jelas dari jawaban masing-masing informan.

Pada tahap persiapan dilakukan sebelum melakukan penelitian, peneliti melewati beberapa prosedur, yakni: Mengajukan sinopsis judul dan mendapatkan persetujuan judul penelitian, melaksanaan ujian proposal, melakukan uji kaji etik dan mendapatkan surat persetujuan untuk melakukan penelitian, mengajukan permohonan tertulis kepada institusi yakni Ka. Prodi Magister Keperawatan Universitas Muhammadiyah Jakarta untuk memberikan surat keterangan bahwa akan melaksanakan penelitian di ruang HD RSUD Kabupaten Tangerang, meminta ijin kepada semua tim yang terlibat dan bertanggung jawab terhadap perawatan dan pengobatan responden yang diteliti, menjelaskan maksud dan tujuan penelitian serta membuat kontrak kerja terhadap lamanya penelitian. Pada tahap ini peneliti mengurus perijinan tempat penelitian dengan membawa surat permohonan ijin penelitian dari Ka. Prodi Magister Keperawatan Universitas Muhammadiyah Jakarta yang ditujukan kepada direktur RSUD Kabupaten Tangerang, direktur keperawatan RSUD Kabupaten Tangerang dan terakhir pada Diklat RSUD Kabupaten Tangerang.

Pada tahap persiapan instrumen peneliti mempersiapkan instrumen yang digunakan untuk pengumpulan data berupa Standar Operasional Prosedur (SOP) pelaksanaan relaksasi autogenic dan music therapy serta format pengkajian karakteristik responden dan lembar observasi skala nyeri Visual Analoge Scale (VAS). Pada prosedur teknis peneliti melakukan koordinasi dan sosialisasi rencana penelitian. Peneliti melakukan intervensi sendiri dan melakukan pengukuran nyeri sendiri terhadap 
responden. Penelitian ini dilakukan selama 4 minggu, sesuai dengan jadwal HD hingga mencapai jumlah sampel yang diinginkan.

Adapun prosedur teknis pengambilan data yakni dengan cara: Peneliti memilih responden sesuai kriteria inklusi (terpasang akses permanen) dengan melihat pada buku jadwal daftar responden HD hari senin dan kamis dan jenis akses yang digunakan, memperkenalan diri serta menjelaskan tujuan dari penelitian. Responden yang menyetujui untuk terlibat dalam penelitian diberikan form lembar persetujuan sebagai responden dan menandatangani form persetujuan. Peneliti meminta keluarga untuk menunggu di ruang tunggu responden. Peneliti meminta responden untuk tidur terlentang diatas tempat tidur responden sambil menanyakan data responden (usia, jenis kelamin, lama HD). Setelah data terkumpul peneliti memulai mengajarkan fase-fase latihan relaksasi autogenic sesuai SOP. Peneliti memberikan kesempatan pada responden untuk bertanya jika ada yang lupa atau terlewatkan mengenai tehnik relaksasi. Setelah medical record responden sudah datang dan proses insersi akan dimulai, peneliti meminta responden untuk fokus dengan memejamkan mata sambil merasakan perintah otak untuk semua anggota badan dalam keadaan relaksasi dan memulai tehnik relaksasi autogenic.

Peneliti meminta responden untuk memulai tehnik relaksasi lima menit sebelum perawat mulai insersi vaskuler dan menghentikannya saat peneliti menginstruksikan untuk selesai dengan melihat jam tangan dan mengukurnya dari responden mulai melakukan relaksasi autogenic hingga perawat ruangan mulai insersi vaskuler. Peneliti menjauh dari area insersi responden sambil memonitor responden hingga lima menit setelah selesai insersi peneliti datang untuk menanyakan tingkat nyeri yang dirasakan saat insersi dilakukan. Pada proses terapi music juga sama yakni mendengarkan music dengan terlebih dahulu mengecek kesejajaran dan kenyamanan sound headphone dengan telinga responden dan memutarkan musik dari lima menit proses insersi akan dilakukan hingga lima menit setelah dilakukan. Setelah selesai mendapatkan data peneliti mengucapkan salam dan berterimakasih atas kesediaan menjadi responden. Mencocokkan data responden dengan medical record responden.

\section{HASIL PENELITIAN}

\section{Karakteristik Responden (Usia, Lama HD dan Jenis Kelamin)}

Tabel. 1

Distribusi Responden Berdasarkan

Usia, Jenis Kelamin, Lama HD

\begin{tabular}{|c|c|c|c|c|c|c|c|}
\hline No & Variabel & Kategorik & (f) & $(\%)$ & Mean & SD & $\begin{array}{l}\text { Min- } \\
\text { Max }\end{array}$ \\
\hline \multirow[t]{4}{*}{1} & Usia & & & & & & \\
\hline & Relaksasi autogenic & - & 66 & 100 & 50,00 & 2,353 & $45-55$ \\
\hline & Music therapy & - & 66 & 100 & 50,00 & 2,353 & $45-55$ \\
\hline & $\begin{array}{l}\text { Gabungan relaksasi } \\
\text { autogenic dengan music } \\
\text { therapy }\end{array}$ & - & 33 & 100 & 50,21 & 2,616 & $45-55$ \\
\hline \multirow[t]{4}{*}{2} & Lama HD & & & & & & \\
\hline & Relaksasi autogenic & - & 66 & 100 & 6,00 & 2,353 & $1-11$ \\
\hline & Music therapy & - & 66 & 100 & 6,00 & 2,353 & $1-11$ \\
\hline & $\begin{array}{l}\text { Gabungan relaksasi } \\
\text { autogenic dengan music } \\
\text { therapy }\end{array}$ & - & 33 & 100 & 5,97 & 2,353 & $1-11$ \\
\hline
\end{tabular}




\begin{tabular}{lccc}
\hline 3 & & & \\
Jenis Kelamin & Laki-laki & 43 & 65,2 \\
Relaksasi autogenic & Perempuan & 23 & 34,8 \\
Music therapy & Laki-laki & 43 & 65,2 \\
& Perempuan & 23 & 34,8 \\
Gabungan relaksasi & Laki-laki & 25 & 75,8 \\
autogenic dengan music & Perempuan & 8 & 24,2 \\
therapy &
\end{tabular}

Berdasarkan tabel 1 menunjukkan hasil bahwa responden yang memiliki rata-rata usia tertinggi adalah kelompok gabungan relaksasi autogenic dengan music therapy yaitu 50,21 ( $\mathrm{SD}=2,369)$ dengan usia responden minimal 45 tahun dan maksimal 55 tahun. Jenis kelamin responden terbanyak adalah laki-laki, pada kelompok relaksasi autogenic dan music therapy berjumlah $43(65,2 \%)$ sedangkan gabungan relaksasi autogenic dengan music therapy 25 (75,8\%). Rata-rata lama HD terendah adalah kelompok gabungan relaksasi autogenic dengan music therapy yaitu 5,97 tahun $(\mathrm{SD}=2,616)$ dengan lama HD responden minimal 1 tahun dan maksimal 11 tahun.

\section{Rata-Rata Nilai Nyeri Sesudah Perlakuan pada Kelompok Relaksasi Autogenic, Music Therapy dan Gabungan Relaksasi Autogenic dengan Music Therapy}

Tabel. 2

Rata-Rata Nilai Nyeri Sesudah Perlakuan pada Kelompok Relaksasi Autogenic, Music Therapy dan Gabungan Relaksasi Autogenic dengan Music Therapy

\begin{tabular}{cccccr}
\hline \multicolumn{7}{c}{ Tingkat nyeri (Visual Analoge Scale) } \\
\hline Kelompok & Pengukuran & Mean & SD & Min-Max & 95 \%CI \\
\hline Relaksasi autogenic & Post Test & 5,27 & 2,453 & $1-10$ & $4,67-5,88$ \\
\hline $\begin{array}{c}\text { Music therapy } \\
\begin{array}{c}\text { gabungan relaksasi } \\
\text { autogenic dengan } \\
\text { music therapy }\end{array}\end{array}$ & Post Test & 5,00 & 2,294 & $1-9$ & $4,44-5,56$ \\
\hline
\end{tabular}

Berdasarkan tabel 2 menunjukkan hasil bahwa pada kelompok relaksasi autogenic didapatkan rata-rata nilai nyeri setelah perlakuan yaitu 5,27 $(\mathrm{SD}=2,453)$. Dengan tingkat kepercayaan 95\% rata-rata tingkat nyeri diyakini antara 4,67-5,88. pada kelompok music therapy didapatkan rata-rata nilai nyeri setelah perlakuan yaitu 5,00 (SD=2,294). Dengan tingkat kepercayaan $95 \%$ rata-rata tingkat nyeri diyakini antara 4,44-5,56. Pada kelompok gabungan relaksasi autogenic dengan music therapy didapatkan rata-rata nilai nyeri setelah perlakuan yaitu 5,06 $(\mathrm{SD}=1,903)$. Dengan tingkat kepercayaan $95 \%$ rata-rata tingkat nyeri diyakini antara 4,39-5,74. 


\section{Perbedaan Tingkat Nyeri Setelah Perlakuan pada Kelompok Relaksasi Autogenic dan Music Therapy}

Tabel. 3

Perbedaan Tingkat Nyeri Setelah Perlakuan pada Kelompok Relaksasi Autogenic dan Music Therapy

\begin{tabular}{cccccc}
\hline Tingkat nyeri & Mean & SD & SE & P value & N \\
\hline post relaksasi autogenic & 5,27 & 2,453 & 0,302 & \multirow{2}{*}{0,463} & \multirow{2}{*}{66} \\
Post music therapy & 5,00 & 2,294 & 0,282 & & \\
\hline
\end{tabular}

Berdasarkan tabel 3 menunjukkan rata-rata tingkat nyeri setelah intervensi relaksasi autogenic $(5,27)$, SD $(2,453)$ sedangkan setelah intervensi music therapy didapatkan rata-rata tingkat nyeri $(5,00)$, SD $(2,294)$. Hasil uji statistic didapatkan nilai $\mathrm{p}=(0,463)$ dapat disimpulkan tidak ada perbedaan yang signifikan tingkat nyeri setelah mendapatkan intervensi relaksasi autogenic dan setelah mendapatkan music therapy.

\section{Perbedaan Tingkat Nyeri Setelah Perlakuan pada Kelompok Relaksasi Autogenic dan Gabungan Relaksasi Autogenic dengan Musik}

Tabel. 4

Perbedaan Tingkat Nyeri Setelah Perlakuan pada Kelompok Relaksasi Autogenic dan Gabungan Relaksasi Autogenic dengan Music Therapy

\begin{tabular}{cccccc}
\hline Tingkat nyeri & Mean & SD & SE & P value & N \\
\hline $\begin{array}{c}\text { Setelah relaksasi } \\
\text { autogenic }\end{array}$ & 5,27 & 2,453 & 0,302 & 0,664 & 66 \\
$\begin{array}{c}\text { Setelah intervensi } \\
\text { gabungan relaksasi }\end{array}$ & 5,06 & 1,903 & 0,331 & & 33 \\
$\begin{array}{c}\text { autogenic } \text { dengan } \text { music } \\
\text { therapy }\end{array}$ & & & & & \\
\hline
\end{tabular}

Berdasarkan tabel 4 menunjukkan rata-rata tingkat nyeri setelah relaksasi autogenic adalah $(5,27)$ dengan standar deviasi $(2,453)$ sedangkan setelah mendapatkan intervensi gabungan relaksasi autogenic dengan music therapy didapat rata-rata tingkat nyeri adalah $(5,06)$ dengan standar deviasi $(1,903)$. Hasil uji statistik didapatkan nilai $\mathrm{p}=(0,664)$ maka dapat disimpulkan tidak ada perbedaan yang signifikan rata-rata tingkat nyeri setelah relaksasi autogenic dengan intervensi gabungan relaksasi autogenic dengan music therapy.

\section{Perbedaan Tingkat Nyeri Setelah Perlakuan pada Kelompok Music Therapy dan Gabungan Relaksasi Autogenic dengan Music Therapy}

Tabel. 5

Perbedaan Rata-Rata Tingkat Nyeri Setelah Perlakuan pada Kelompok Music Therapy dan Gabungan Relaksasi Autogenic dengan Music Therapy

\begin{tabular}{|c|c|c|c|c|c|}
\hline Tingkat nyeri & Mean & SD & SE & $\mathrm{P}$ value & $\mathrm{N}$ \\
\hline Setelah music therapy & 5,00 & 2,294 & 0,282 & 0,896 & 66 \\
\hline $\begin{array}{c}\text { Setelah intervensi } \\
\text { gabungan relaksasi } \\
\text { autogenic dengan music } \\
\text { therapy }\end{array}$ & 5,06 & 1,903 & 0,331 & & 33 \\
\hline
\end{tabular}


Rata-rata tingkat nyeri setelah music therapy adalah $(5,00)$ dengan standar deviasi $(2,294)$ sedangkan setelah intervensi gabungan relaksasi autogenic dengan music therapy didapat rata-rata tingkat nyeri adalah $(5,06)$ dengan standar deviasi $(1,903)$. Hasil uji statistik didapatkan nilai $\mathrm{p}=(0,896)$ maka dapat disimpulkan tidak ada perbedaan yang signifikan rata-rata tingkat nyeri setelah mendpatkan music therapy dengan setelah intervensi gabungan relaksasi autogenic dengan music therapy.

\section{PEMBAHASAN \\ Karakteristik responden Jenis kelamin}

Hasil penelitian ini menunjukkan bahwa responden dengan jenis kelamin lakilaki jumlahnya lebih banyak baik pada kelompok pertama dan kedua.

Penelitian yang dilakukan oleh Gill (1990) mengungkapkan laki-laki dan wanita tidak mempunyai perbedaan secara signifikan mengenai respon mereka terhadap nyeri. Begitu juga dengan hasil penelitian yang dilakukan oleh Purwanti et al., (2010) yang menyatakan bahwa tidak terdapat pengaruh yang signifikan antara jenis kelamin dengan tingkat nyeri.

\section{Usia}

Rata-rata usia responden yang menjalani HD pada kelompok pertama adalah 50,00 sedangkan kelompok kedua 50,21 tahun. Usia termuda responden adalah 45 tahun dan usia tertua adalah 55 tahun. Rata-rata usia responden berdistribusi diantara 49,48 tahun sampai dengan 50,54 tahun.

Peneliti mencoba menganalisa beberapa faktor yang berpotensi mempengaruhi hasil penelitian ini dengan membandingkan dengan teori yang sudah ada. Menurut Potter \& Perry (2005) usia adalah variabel penting yang mempengaruhi nyeri terutama pada anak dan orang dewasa. Perbedaan perkembangan yang ditemukan antara kedua kelompok usia ini dapat mempengaruhi bagaimana anak dan orang dewasa bereaksi terhadap nyeri.

Pada orang dewasa kadang melaporkan nyeri jika sudah patologis dan mengalami kerusakan fungsi (Tamsuri, 2007). Pada saat diruangan peneliti menemukan bahwa responden mengatakan sudah terbiasa dengan insersi. Sebagian besar responden HD mendapatkan terapi HD 2-3 kali dalam seminggu. Mereka sering terpapar dengan pengalaman insersi vaskuler. Pada proses penelitian mengunakan responden yang tidak memiliki masalah dengan akses vaskuler sehingga proses HD berlangsung lancar. Kondisi tersebut juga mempengaruhi jawaban responden dalam mengungkapkan tingkat nyeri yang dirasakan.

Hasil penelitian ini sama dengan hasil penelitian yang disampaikan oleh Erwinsyah (2009) mengadakan penelitian terhadap 32 orang responden di Unit HD RSUD Raden Mattaher menyatakan hasil yang sama dengan penelitian ini bahwa ratarata usia responden adalah 50,59 tahun yang terdistribusi antara usia 46,33-54,86 tahun.

\section{Lama HD}

Rata-rata lama pengalaman responden menjalani terapi HD pada kelompok pertama adalah 6,00 tahun sedangkan kelompok kedua 5,97 tahun. Pengalaman termuda responden adalah 1 tahun dan pengalaman terlama adalah 11 tahun. 
Taddio et al., (2009) menyatakan bahwa pengalaman awal terhadap nyeri dapat memiliki efek negatif jangka panjang pada perkembangan ambang nyeri, sensitivitas, koping strategi dan persepsi terhadap nyeri. Apabila seseorang telah memiliki pengalaman yang berulang tentang nyeri yang sejenis namun telah dapat ditangani, maka hal tersebut akan memudahkan untuk menginterpretasikan sensasi nyeri Perry \& Potter (2009) meskipun pengalaman merupakan salah satu faktor dalam mengintegrasikan rangsang nyeri, namun sangatlah penting intervensi atraumatic care untuk mengurangi dampak negatif jangka panjang dan pengalaman negatif yang berkelanjutan.

\section{Perbandingan Rata-Rata Tingkat Nyeri Setelah Perlakuan pada Kelompok Relaksasi Autogenic dan Music Therapy}

Nilai rata-rata tingkat nyeri post insersi vaskuler HD setelah intervensi music therapy lebih rendah dibandingkan dengan relaksasi autogenic. hal ini menunjukkan bahwa terdapat perbedaan rata-rata tingkat nyeri pada responden HD walaupun secara uji statistic tidak terdapat perbedaan efektifitas antara relaksasi autogenic dan music therapy terhadap tingkat nyeri post insersi akses vaskuler responden HD.

Sesuai dengan pendapat Lindquish (2014) terapi music digunakan sebagai media untuk menunjang proses penyembuhan suatu penyakit tertentu, cara kerjanya yaitu dengan memberikan stimulasi eksternal melalui saraf auditori. Music religius lebih disukai dan disambut oleh mereka yang tidak mampu menghadiri pelayanan rohani, dan untuk menghadirkan keyakinan akan sembuh pada responden yang memiliki keyakinan akan adanya tuhan dan intervensi tambahan untuk manajemen rasa sakit. Music therapy secara tidak langsung mempengaruhi tingkat nyeri saat dilakukan insersi pemasangan akses HD.

Hasil penelitian ini sesuai dengan penelitian yang dilakukan Purwanti et al., (2010) tentang penurunan tingkat nyeri anak prasekolah yang menjalani penusukan intravena untuk pemasangan infus melalui terapi musik, menyimpulkan terapi music efektif menurunkan nyeri.

Saat penelitian terlihat responden menikmati ritme music dengan hikmat dan terlihat nyaman. Sesuai dengan pendapat Kozier (2011) perasaan nyaman (comfort) dapat menstimulasi tubuh untuk memproduksi asam amino yang berfungsi mengikat reseptor opiat. Reseptor opiat dapat memberikan efek analgesik atau sebagai endorfin.

Selaras dengan yang dikemukakan Melzack \& Wall (1965) dalam Potter \& Perry (2009) teori gate control pada nyeri, terjadi mekanisme syaraf pada dorsal horn yang bertindak sebagai sebuah gerbang yang mengubah aliran impuls syaraf dari serat aferen didalam perifer menuju ke sel-sel spinal cord yang memproyeksikan ke otak. Input somatik bertugas memodulasi pengaruh mekanisme gerbang spinal di dalam substansia gelatinosa sebelum membangkitkan persepsi dan respon nyeri. Serabut syarat yang berdiameter besar cenderung menutup pintu sehingga sinyal nyeri tidak dapat masuk melalui medulla spinalis sedangkan serabut syaraf berdiameter kecil cenderung membuka pintu sehingga sinyal nyeri dapat masuk melalui medula spinalis ke otak. Teori ini menunjukkan bahwa sinyal nyeri dapat dipengaruhi dengan cara menstimulasi lokasi nyeri perifer sehingga pintu akan tertutup dan akhirnya dapat mengurangi rasa nyeri, hal ini dapat didukung dengan adanya intervensi non farmakologis terkait manajemen nyeri. 
Saat dilakukan penelitian terlihat fokus responden terpecah karena perasaan khawatir aksesnya akan gagal dan keluhan sesak karena kelebihan cairan yang menyertai responden gagal ginjal sebelum dilakukan tindakan dialysis.

Sesuai dengan pendapat Saunder (2007) relaksasi autogenic bersumber dari diri sendiri dan bekerja dengan mengaktifkan konsentrasi/focus dengan mengalihkan respon tubuh secara sadar berdasarkan perintah sendiri. Atensi adalah fokus dan konsentrasi merupakan usaha mental yang menghasilkan kesadaran oleh rangsangan sensorik eksternal, yang ditangkap melalui panca indra atau pengalaman yang membutuhkan upaya mental atau fungsi kognitif (Brown, 2007).

\section{Perbandingan Rata-Rata Tingkat Nyeri Setelah Perlakuan pada Kelompok Relaksasi Autogenic dan Gabungan Relaksasi Autogenic dengan Music Therapy}

Nilai rata-rata tingkat nyeri setelah intervensi relaksasi autogenic lebih tinggi dibandingkan dengan gabungan relaksasi autogenic dengan music therapy.

Pada kelompok yang mendapatkan intervensi gabungan relaksasi autogenic dengan music therapy terdapat dua penggabungan fungsi otak yakni fungsi atensi dan pengaktiifan fungsi system nervus auditori. Melalui suara music panca indra diransang oleh suara music ditambah keyakinan dari dalam diri dimunculkan untuk memerintahkan tubuh menjadi relaksasi. Dimana kita ketahui fungsi system saraf sangat kompleks dan dapat bekerja secara bolak balik.

Sesuai dengan pendapat Sternberg et al., (2008) Otak merupakan organ penting dan terdiri atas milyaran sel saraf. Sel Saraf berfungsi untuk menghantarkan impuls listrik dari suatu rangsangan (Stimulus). Rangsangan dari suara music dan keinginan untuk mengontrol pikiran, emosi, dan motivasi sehingga menghadirkan rasa relaksasi dimaka akan timbul rasa bahagia dan relaks.

Sesuai dengan pendapat Simon \& David (2008) rasa bahagia dan nyaman merangsang pelepasan hormone endorphin yang berperan dalam penurunan nyeri. Dalam penelitian ini terlihat rata-rata tingkat nyeri berkurang pada kelompok yang mendapatkan intervensi gabungan relaksasi autogenic dan music therapy.

\section{Perbandingan Rata-Rata Tingkat Nyeri Setelah Perlakuan pada Kelompok Music Therapy dan Gabungan Relaksasi Autogenic dengan Music Therapy}

Nilai rata-rata tingkat nyeri setelah intervensi music therapy lebih rendah dibandingkan dengan gabungan relaksasi autogenic dengan music therapy. Walaupun secara uji statistic kedua kelompok tidak terdapat perbedaan yang signifikan efektifitas music therapy dibandingkan dengan gabungan relaksasi autogenic dengan music therapy terhadap tingkat nyeri post insersi akses vaskuler HD.

Relaksasi autogenic dan music therapy dapat memberikan perasaan nyaman pada responden HD sehingga menimbulkan perasaan terkontrol. Pada proses penelitian,

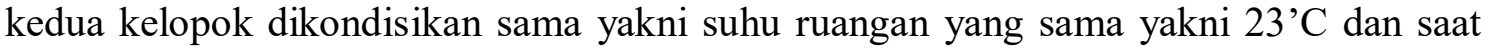
mulai persiapan keluarga menunggu di ruang tunggu yang terpisah dengan responden. Begitu juga dengan saat insersi akan dimulai, kedua kelompok diperlakukan sama yakni intervensi diberikan 5 menit sebelum dilakukan tindakan invasive dan diukur 5 menit setelah tindakan pemasangan akses selesai sehingga dapat memberikan kenyamanan dan tidak menggangu proses dialysis responden.

Hasil penelitian ini sesuai dengan yang dilakukan oleh Dian (2015) tentang pengaruh terapi relaksasi autogenic terhadap skala nyeri sendi pada lansia diwilayah kerja puskesmas Andalas Padang menyimpulkan bahwa ada pengaruh yang signifikan. 
Priyo (2017) tentang terapi relaksasi autogenic untuk menurunkan tekanan darah dan sakit kepala pada lansia hipertensi di daerah rawan bencana merapi menyimpulkan ada pengaruh yang signifikan.

\section{SIMPULAN}

Karakteristik responden yang menjalani terapi hemodialisis paling banyak adalah laki-laki. Rata-rata umur responden adalah 50 tahun dengan umur termuda adalah 45 tahun dan umur tertua adalah 55 tahun. Rata-rata lama responden menjalani terapi HD adalah 5,97 tahun. Pengalaman termuda responden adalah 1 tahun dan pengalaman terlama adalah 11 tahun. Rata-rata tingkat nyeri setelah intervensi relaksasi autogenic adalah 5,27.

Rata-rata tingkat nyeri setelah intervensi setelah music therapy adalah 5,00. Ratarata tingkat nyeri setelah intervensi gabungan relaksasi autogenic dan music therapy adalah 5,06. Tingkat nyeri terendah adalah 1 dan tertinggi adalah 10 .

Tidak terdapat perbedaan tingkat nyeri yang signifikan setelah insersi akses vaskuler pada responden HD yang diberikan relaksasi autogenic dengan responden HD yang diberikan music therapy. Tidak terdapat perbedaan tingkat nyeri yang signifikan setelah insersi akses vaskuler pada responden HD yang diberikan relaksasi autogenic dengan responden HD yang diberikan gabungan dari relaksasi autogenic dan music therapy. Tidak terdapat perbedaan tingkat nyeri yang signifikan setelah insersi akses vaskuler pada responden HD yang diberikan music therapy dengan responden HD yang diberikan gabungan dari relaksasi autogenic dan music therapy.

\section{SARAN}

\section{Bagi Institusi Pelayanan Khususnya Unit HD}

Mencoba menerapkan managemen nyeri non farmakologi music therapy dan relaksasi autogenic pada responden dengan selalu memperhatikan kenyamanan dan tingkat nyeri responden.

Melakukan penilaian/evaluasi terhadap efektifitas relaksasi autogenic dan music therapy dalam pelaksanaan intervensi manajemen nyeri non farmakologi.

\section{Bagi Ilmu Keperawatan}

Perlu dilakukan suatu diskusi secara periodik antar perawat HD tentang peranan perawat dalam managemen nyeri sehingga dapat dikembangkan suatu metode yang tepat tentang managemen nyeri non farmakologi.

\section{Bagi Perawat Spesialis Medikal Bedah}

Perawat spesialis medikal bedah dapat melakukan penelitian lebih lanjut untuk mendapatkan metode yang tepat dalam manajemen nyeri non farmakologi dan faktor-faktor yang berkontribusi mempengaruhi tingkat nyeri saat insersi akses hemodialisis yang optimal.

\section{Bagi Peneliti Selanjutnya}

Penelitian kuantitatif tentang perbedaan efektifitas relaksasi autogenic dan music therapy perlu dilanjutkan dengan jumlah sampel yang lebih banyak, tempat/lokasi penelitian yang berbeda dan durasi pelaksanaan yang lebih bervariasi. 
Mengembangkan penelitian tentang pengaruh jenis music terhadap tingkat nyeri saat insersi akses hemodialisis.

Mengembangkan penelitian tentang faktor dominan yang mempengaruhi tingkat nyeri.

Mengembangkan penelitian tentang faktor-faktor yang mempengaruhi perempuan yang menjalani terapi HD jumlahnya lebih sedikit dibandingkan dengan laki-laki.

\section{DAFTAR PUSTAKA}

Alhani, S, A., \& Hajizadeh, H. (2008). The Effect of Programed Distraction on the Pain Caused by Venipuncture amoung Adolescents on Hemodialysis. Pain Managemen Nursing, 11, 85-91

Black, J. M., \& Hawks, J. H. (2009). Medical Surgical Nursing Clinical Management for Positive Outcomes (7th Ed). St Louis Missouri: Elsevier Saunders

Brown, H. D. (2007). Prinsip Pembelajaran dan Pengajaran Bahasa, Edisi Kelima. Jakarta: Kedutaan Besar Amerika Serikat di Jakarta

Dian, D. (2015). Pengaruh Terapi Relaksasi Autogenic terhadap Skala Nyeri Sendi pada Lansia di Wilayah Kerja Puskesmas Andalas Padang. Jurnal Keperawatan Unand

Dina. F. (2016). Perbandingan Pemberian Terapi Relaksasi Autogenic dan Aroma Terapi terhadap Penurunan Tingkat Nyeri Haid pada Remaja Putri. http://www.id.stikes-mataram.ac.id/e-journal/index.php/JPRI/article/

Erwinsyah, E. (2009). Hubungan antara Qb dengan Penurunan Kadar Ureum dan Kreatinin Plasma pada Pasien Hemodialisis di RSUD Raden Mattaher Jambi, Tesis, MSc. Universitas Indonesia

Gill, K. (1990). Psychologic Aspect of Acute Pain. Anesthesiol Rep, 2(2), 246

Greenberg, J. S. (2002). Comprehensive Stress Management (7th ed). New York: The McGraw-Hill Companies

Guyton, A. C., \& Hall, J. E. (2006). Buku Ajar Fisiologi Kedokteran. Edisi 11. Penterjemah: Irawati, Ramadani D, Indriyani F. Jakarta: Kedokteran EGC

Indonesian Renal Registry. (2015). 8th Report of Indonesian Renal Registry: Jakarta. https://www.indonesianrenalregistry.org

International Association for the Study of Pain. (1979). IASP Taxonomy. IASP Web Site. dari http:// www.iasp-pain. org/Conten/Navigation Menu/General Resource Links/Pain Definitions/default.htm

Kozier, B. (2011). Fundamental Keperawatan. Jakarta: EGC

Lindquist, R., Snyder, M., \& Mary, F. T. (2014). Complementary and Alternative Therapies in Nursing. United States : Springer Publishing Company

Melzack, R., \& Wall, P. D. (1965). Pain Mechanism: A New Theory : Science 150 : 971-979

Micah, R., \& Sadigh, S. (2001). Autogenic training. New York • London • Oxford. The Haworth Medical Press ${ }^{\circledR}$ An Imprint of The Haworth Press, Inc

Pardede, R. (2006). Komponen Utama Sistem Hemodialisis: Kumpulan Makalah Kursus Perawatan Intensif Ginjal PPSDM RS PGI Cikini. Jakarta: Tidak Dipublikasikan

Potter, P. A., \& Perry, A. G. (2005). Buku Ajar Fundamental Keperawatan Konsep, Proses dan Praktik. Edisi 4. Jakarta: EGC

Potter, P., \& Perry, P. (2009). Fundamental Keperawatan. Edisi 7. Jakarta: Salemba Medika 
Priyo, P. (2017). Terapi Relaksasi Autogenic untuk Menurunkan Tekanan Darah dan Sakit Kepala pada Lansia Hipertensi di Daerah Rawan Bencana Merapi. University research colloquium: Urecol

Purwanti, N. H., Rustina, Y., \& Sabri, L. (2010). Penurunan Tingkat Nyeri Anak Prasekolah yang Menjalani Penusukan Intravena untuk Pemasangan Infus melalui Terapi Musik. Jurnal Keperawatan Indonesia, 13(1), 49-53. DOI: 10.7454/jki.v13i1.231. http://www.jki.ui.ac.id/index.php/jki/article/view/231

Saunders, S. (2007). Autogenic Theraphy: Short Term Theraphy for Long Term Gain. Brithish Autogenic Society, Chairma. http://www.autogenic-teraphy.org.uk

Simon, G., \& David, A. (2008). Music Theraphy and Trauma Brain Injury. London N1 9JB, UK. Philadelphia: Jessica Kingsley Publishers

Smeltzer, S. C., \& Bare, B.G. (2008). Buku Ajar Keperawatan Medikal Bedah Brunner \& Suddarth (Agung Waluyo, Kariasa, Julia, Y. Kuncara,Yasmin Asih, Penerjemah). Jakarta: EGC

Sternberg, R. J., Jarvin, L., \& Reznitskaya, A. (2008). Teaching of Wisdom Through History: Infusing Wise Thinking Skills the School Curriculum. In M. Ferrari \& G

Sudoyo, A. W., Sutiyahadi, B., Alwi, I., Simadibrata, M., \& Setiati, S. (2006). Buku Ajar Ilmu Penyakit Dalam, Jilid II Edisi Ke IV. Jakarta: Pusat Penerbitan Departemen Ilmu Penyakit Dalam Fakultas Kedokteran Universitas Indonesia

Suko, P. (2016). Pengaruh Kompres Dingin terhadap Tingkat Nyeri Pasien Hemodialisa saat Terpasang Akses Inlet Hemodialisa jurnal Alirsyad. http://stikesalirsyadclp.ac.id/jka/index.php/jka/article/view/58

Taddio, A., Chambers, S., \& Halperin, H. (2009). Inadequate Pain Management during Routine Childhood Immunizations: The Nerve of It. Clinical Therapeutics, 31(C). pp.S152-S167. Available at: http://dx.doi.org/10.1016/j.clinthera.2009.07.022

Tamsuri, A. (2007). Konsep dan Penatalaksanaan Nyeri. Jakarta: EGC. Hlm 1-63 PA 19106, USA 